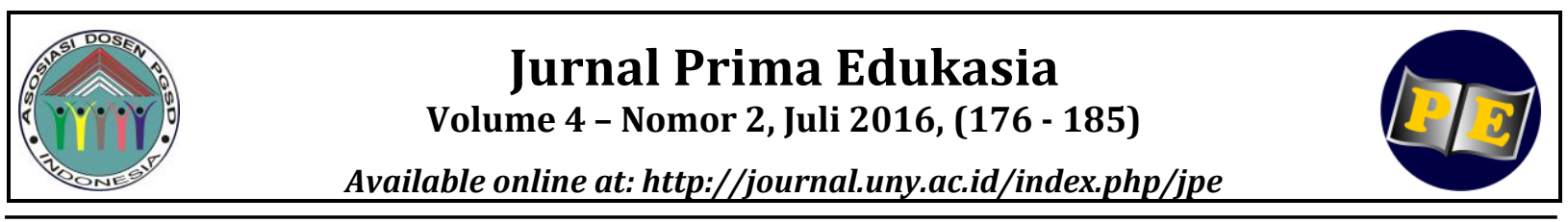

\title{
PENGEMBANGAN PERANGKAT PEMBELAJARAN TEMATIK-INTEGRATIF BERBASIS SASTRA BAGI SISWA KELAS V SEKOLAH DASAR
}

\author{
Nurul Mu'minin MZ ${ }^{1)}$, Suhardi ${ }^{2)}$ \\ ${ }^{1}$ Pendidikan Guru Sekolah Dasar, STKIP Hamzanwadi Selong. Jalan TGKH Muhammad Zainuddin \\ Abdul Masjid, RT.25 RW.10 lingk. Bermi, Pancor, Selong, Lombok Timur, 83611, Indonesia. \\ ${ }^{2}$ Pendidikan Bahasa dan Sastra Indonesia, Universitas Negeri Yogyakarta. Jalan Colombo No.1 \\ Karangmalang, Yogyakarta 55281, Indonesia. \\ Email: ${ }^{1}$ mzmuminin@gmail.com, ${ }^{2}$ suhardiuny@yahoo.com
}

\begin{abstract}
Abstrak
Penelitian ini bertujuan untuk: (1) menghasilkan perangkat pembelajaran tematik integratif berbasis sastra yang layak bagi siswa kelas V SD, (2) mengetahui efektivitas perangkat pembelajaran tematik integratif berbasis sastra bagi siswa kelas V SD. Penelitian dan pengembangan mengacu pada langkah yang dikembangkan Borg \& Gall. Desain pengembangan dikelompokkan menjadi 3 langkah: (1) studi pendahuluan, (2) proses pengembangan, dan (3) uji coba dan finalisasi. Uji lapangan operasional dilakukan di SD Negeri 3 Pancor dan SD Negeri 3 Selong dengan jumlah subjek 102 orang siswa. Pengumpulan data menggunakan pedoman wawancara, lembar angket, lembar observasi, dan soal tes. Teknik analisis data menggunakan Paired Sample t Test, dan Independent Sample t Test dengan taraf signifikansi 0,05 . Hasil penelitian menunjukkan perangkat pembelajaran tematik integratif berbasis sastra hasil pengembangan menurut ahli (expert judgment) berkategori "baik". Terdapat perbedaan signifikan nilai hasil akhir pembelajaran antara kelas kontrol dengan kelas eksperimen setelah menggunakan produk hasil pengembangan perangkat pembelajaran tematik integratif berbasis sastra dengan $p<0,05$, dan $p=0,002$.
\end{abstract}

Kata Kunci: perangkat pembelajaran, tematik integratif, pembelajaran berbasis sastra.

\section{DEVELOPING THEMATIC INTEGRATIVE LEARNING INSTRUMENTS BASED ON LITERATURE FOR FIFTH GRADE ELEMENTARY SCHOOL STUDENT}

\begin{abstract}
This study aims to: (1) produce an integrated thematic learning instruments based on literature, that is eligible for fifth grade elementary school student, (2) determine the effectiveness of the thematic integrative learning instrument based on literature for fifth grade elementary school student. The research and development refers to the model developed by Borg \& Gall. The design development is grouped into three steps, namely: (1) preliminary study, (2) the process of development, and (3) testing and finalization. Operational field test conducted in SD Negeri 3 Pancor dan SD Negeri 3 Selong subjects totaled 102 students. Collecting data used interviews, questionnaire sheets, observation sheets, and tests. Data were analyzed using Paired Sample t Test, and independent sample t test with significance level of 0.05. The results show the development of learning outcomes-based learning instrument thematic integrative literature according to the expert (expert judgment) is categorized as "good". There are significant differences in the value of learning outcomes between the control class and the experimental class after using the learning outcomes of thematic integrative learning instrument based on literature with $p<0.05$, and $p=0.002$.
\end{abstract}

Keywords: learning instrument, thematic integrative, literature-based learning.

How to Cite: MZ, N., \& Suhardi, S. (2016). Pengembangan perangkat pembelajaran tematik-integratif berbasis sastra bagi siswa kelas V Sekolah Dasar. Jurnal Prima Edukasia, 4(2), 176-185. doi:http://dx.doi.org/10.21831/jpe.v4i2.7717

Permalink/DOI: http://dx.doi.org/10.21831/jpe.v4i2.7717 
Jurnal Prima Edukasia, 4 (2), Juli 2016 - 177

Nurul Mu'minin MZ, Suhardi

\section{Pendahuluan}

Undang-Undang tentang Sistem Pendidikan Nasional Nomor 20 Tahun 2003 mengamanatkan penyelenggaraan pendidikan yang diharapkan dapat mewujudkan proses berkembangnya kualitas pribadi peserta didik sebagai generasi penerus bangsa pada masa mendatang (Undang-Undang RI, 2010: p.6). Siswa sebagai peserta didik merupakan generasi penerus yang diyakini akan menjadi faktor dominan bagi tumbuh kembangnya bangsa dan negara Indonesia sepanjang zaman. Siswa menjadi pemegang tongkat estafet untuk pelaksanaan pembangunan dalam segala bidang pada era-era selanjutnya. Posisi yang strategis sebagai seorang siswa menjadikan mereka harus dapat dikembangkan potensinya.

Pendidikan menjadi jalan yang paling baik untuk mengembangkan potensi yang dimiliki oleh siswa. Dari sekian banyak sumber daya pendidikan, kurikulum merupakan salah satu unsur yang memberikan kontribusi signifikan untuk mewujudkan proses berkembangnya kualitas potensi siswa. Undang-Undang Nomor 20 Tahun 2003 Pasal 1 Ayat (19) menjelaskan bahwa kurikulum sebagai seperangkat rencana dan pengaturan mengenai tujuan, isi, dan bahan pelajaran serta cara yang digunakan sebagai pedoman penyelenggaraan kegiatan pembelajaran untuk mencapai tujuan pendidikan tertentu. Pengembangan Kurikulum 2013 merupakan langkah baru bagi pemerintah yang disebut sebagai lanjutan Pengembangan Kurikulum Berbasis Kompetensi yang telah dirintis pada tahun 2004 dan KTSP 2006 yang mencakup kompetensi sikap, pengetahuan, dan keterampilan secara terpadu.

Implementasi Kurikulum 2013 pada tahun ke-2 pada SD di Kecamatan Selong, Lombok Timur masih terdapat beberapa kendala. Salah satu kendala yang dirasa menjadi sangat berpengaruh terhadap kegiatan pembelajaran adalah ketersediaan buku panduan guru dan buku teks siswa. Permasalahan selanjutnya yang ditemukan dalam implementasi Kurikulum 2013 tahun ke-2 adalah kedalaman materi yang terdapat dalam buku teks siswa. Materi yang terdapat dalam buku teks siswa dirasa masih sangat dangkal bila dibandingkan dengan materi pada kurikulum-kurikulum sebelumnya. Sekolah tidak melakukan inisiatif untuk memperkaya sumber belajar dengan menggunakan buku pendamping misalnya Lembar Kegiatan Siswa (LKS). Guru juga belum mampu menyusun perangkat pembelajaran yang sesuai dengan tuntutan kurikulum 2013.

Keberhasilan seorang guru dalam pembelajaran sangatlah diharapkan, untuk memenuhi tujuan tersebut diperlukan suatu persiapan yang matang. Sebelum guru mengajar (tahap persiapan) seorang guru diharapkan mempersiapkan bahan yang mau diajarkan, mempersiapkan alat-alat peraga/parktikum yang akan digunakan, mempersiapkan pertanyaan dan arahan untuk memancing siswa aktif belajar, mempelajari keadaan siswa, mengerti kelemahan dan kelebihan siswa, serta mempelajari pengetahuan awal siswa, kesemuanya ini akan terurai pelaksanaannya di dalam perangkat pembelajaran. Suhadi (2007, p.2) mengemukakan bahwa "Perangkat pembelajaran adalah sejumlah bahan, alat, media, petunjuk dan pedoman yang akan digunakan dalam proses pembelajaran". Jenis perangkat pembelajaran yang dikembangkan dalam penelitian ini adalah silabus, RPP, LKS, dan soal tes.

Silabus

O'Brien (2008, p.5) menyatakan bahwa "Sections of the syllabus can communicate not only what you will do to help students meet course objectives but also what students can do to meet the objectives. Maksud dari pernyataan tersebut adalah bagian atau isi silabus dapat memberikan gambaran tidak hanya apa yang akan dilakukan oleh guru untuk membantu siswa dalam belajar namun lebih jauh juga dapat membantu siswa memahami apa yang akan dipelajari.

Silabus dapat membantu guru menentukan langkah-langkah yang akan digunakan dalam kegiatan pembelajaran. Silabus juga memberikan gambaran materi pembelajaran hingga penilaian. Prinsip pengembangan silabus yaitu: (1) ilmiah, (2) relevan, (3) sistematis, (4) konsisten, (5) memadai, (6) memadai, (7) aktual dan kontekstual, dan (8) fleksibel.

\section{RPP}

Perencanaan merupakan bagian penting dalam suatu pembelajaran, seperti yang dinyatakan Moore (2009, p.187) bahwa "planning is essential to achieving excellence in instruction". Perencanaan sangat penting untuk mencapai keunggulan dalam pembelajaran. Guru 
Jurnal Prima Edukasia, 4 (2), Juli 2016 - 178

Nurul Mu'minin MZ, Suhardi

perlu membuat suatu perencanaan terlebih dahulu sebelum melaksanakan pembelajaran.

RPP digunakan guru sebagai pedoman pelaksanaan pembelajaran di kelas. Jakman (2013, p.63) menjelaskan bahwa:

The lesson plan is an outgrowth of theme selection, brainstrorming/webbing, and selection of projects and activities. This involves making a series of choices based on the developmental stages, learning styles, and interests of the children: the goals and objectivies of the program; and the availability of materials, supplies, and resources.

Pernyataan tersebut dapat dijelaskan bahwa rancangan pembelajaran merupakan pengembangan dari tema yang di dalamnya terdapat serangkaian kegiatan yang dikembangkan berdasarkan pada perkembangan anak, gaya belajar, minat peserta didik, tujuan dan sasaran kegiatan, dan ketersediaan perangkat, perlengkapan serta sumber daya.

Prinsip Pengembangan RPP yaitu hal-hal di bawah ini: (1) perbedaan individual peserta didik antara lain kemampuan awal, tingkat intelektual, bakat, potensi, minat, motivasi belajar, kemampuan sosial, emosi, gaya belajar, kebutuhan khusus, kecepatan belajar, latar belakang budaya, norma, nilai, dan/atau lingkungan peserta didik; (2) Partisipasi aktif peserta didik; (3) Berpusat pada peserta didik untuk mendorong semangat belajar, motivasi, minat, kreativitas, inisiatif, inspirasi, inovasi dan kemandirian; (4) Pengembangan budaya membaca dan menulis yang dirancang untuk mengembangkan kegemaran membaca, pemahaman beragam bacaan, dan berekspresi dalam berbagai bentuk tulisan; (5) Pemberian umpan balik dan tindak lanjut RPP memuat rancangan program pemberian umpan balik positif, penguatan, pengayaan, dan remedi; (6) Penekanan pada keterkaitan dan keterpaduan antara KD, materi pembelajaran, kegiatan pembelajaran, indikator pencapaian kompetensi, penilaian, dan sumber belajar dalam satu keutuhan pengalaman belajar; (7) Mengakomodasi pembelajaran tematikterpadu, keterpaduan lintas mata pelajaran, lintas aspek belajar, dan keragaman budaya; (8) Penerapan teknologi informasi dan komunikasi secara terintegrasi, sistematis, dan efektif sesuai dengan situasi dan kondisi.
LKS

Lembar Kerja Siswa atau LKS merupakan lembaran-lembaran berisi tugas yang harus dikerjakan oleh siswa (Madjid, 2007, p.176). LKS juga dapat berfungsi sebagai sarana pembelajaran yang dapat digunakan guru dalam meningkatkan keterlibatan atau aktivitas siswa dalam proses belajar-mengajar.

Pada umumnya, LKS berisi petunjuk praktikum, percobaan yang bisa dilakukan di rumah, materi untuk diskusi, Teka Teki Silang, tugas portofolio, dan soal-soal latihan, maupun segala bentuk petunjuk yang mampu mengajak siswa beraktivitas dalam proses pembelajaran. LKS juga dapat difungsikan sebagai hand out yang dimaksudkan untuk membantu siswa belajar secara terarah (guided discovery activities). Hal ini berarti melalui LKS siswa dapat melakukan aktivitis sekaligus memperoleh semacam ringkasan dari materi yang menjadi dasar aktivitas tersebut (Madjid, 2007, p.177).

Langkah-langkah pengembangan LKS yaitu: (1) menetapkan judul, dan tujuan pembelajaran berdasarkan KD yang ingin dicapai. (2) menganalisis dan menjabarkan KD menjadi indikator dengan langkah-langkah: merumuskan KD yang ingin dicapai; memilih dan menjabarkan materi pembelajaran berdasarkan KD yang ingin dicapai; dan membuat indikator pencapaian KD. Kriteria indikator yang baik yaitu: memuat ciri-ciri tujuan yang hendak diukur; memuat satu kata kerja operasional yang dapat diukur; berkaitan erat dengan materi yang diajarkan; serta dapat dibuat evaluasinya sebanyak 3-5 butir soal. (3) Menetapkan prosedur, jenis, dan alat penilaian yang otentik. (4) Menetapkan alternatif kegiatan (pengalaman belajar) yang dapat memberikan peluang yang optimal kepada siswa untuk mengembangkan keterampilan-keterampilan proses di dalam diri sendiri. (5) Menetapkan dan mengembangkan bahan/media/sumber yang sesuai dengan kemampuan dasar yang akan dicapai, karakteristik siswa, fasilitas (sarana dan prasarana), dan karakteristik lingkungan siswa. (6) Menyusun LKS yang lengkap, yaitu menuangkan hasilhasil yang telah dilakukan menjadi sebuah LKS.

\section{Soal Tes}

Evaluasi pembelajaran merupakan salah satu cara untuk mengetahui hasil belajar peserta didik yang dapat dilakukan melalui tes tertulis. 
Jurnal Prima Edukasia, 4 (2), Juli 2016 - 179

Nurul Mu'minin MZ, Suhardi

Untuk mengetahui apakah materi yang diberikan oleh seorang guru kepada siswa sudah dikuasai mereka, salah satu caranya adalah guru melakukan pengukuran dengan menggunakan tes hasil belajar (Sukardi, 2009, p.139). Tes hasil belajar berisi sejumlah pertanyaan/butir tes yang harus diberikan tanggapan/dijawab siswa.

Tes hasil belajar dapat dijadikan acuan untuk melihat tingkat keberhasilan atau efektivitas guru dalam pembelajaran. Untuk itu tes hasil belajar haruslah dibuat mengacu pada kompetensi dasar yang ingin dicapai, dijabarkan ke dalam indikator pencapaian hasil belajar dan disusun berdasarkan kisi-kisi penulisan butir soal. Hasil belajar dapat diartikan sebagai kemampuan yang dimiliki siswa setelah mengalami proses pembelajaran.

Bentuk tes yaitu (a) pilihan ganda, (b) benar-salah, (c) menjodohkan, (d) isian singkat, dan (e) uraian bebas. Penilaian soal tes dengan masing-masing indikator sebagai berikut: (a) materi, (b) konstruksi, (c) bahasa, (d) manfaat/ kegunaan soal tes (Madjid, 2009, pp.196-199).

Pembelajaran tematik integratif menjadi model pembelajaran yang digunakan dalam Kurikulum 2013. Fogarty (1991, p.92) menyebutkan bahwa model kurikulum terintegrasi merupakan pendekatan yang menggabungkan lintas disiplin ilmu dan juga mengintegrasikan skill, concepts, dan attitude. Pembelajaran tematik terpadu menggunakan tema sebagai pemersatu kegiatan pembelajaran yang memadukan beberapa mata pelajaran. Pada penelitian ini, pembelajaran tematik integratif dilaksanakan dengan berbasis pada pembelajaran sastra, khususnya sastra anak.

Haryadi (2011, p.3) mendefinisikan sastra secara etimologis berasal dari kata sas dan tra. Akar kata sas- berarti mendidik, mengajar, memberikan instruksi, sedangkan akhiran -tra menunjukkan pada alat. Jadi, sastra secara etimologis berarti alat untuk mendidik, alat untuk mengajar, dan alat untuk memberi petunjuk. Ismawati (2013, p.68) menyebutkan apreasisi merupakan kegiatan menggauli, menggeluti, memahami, dan menikmati, hingga tumbuh pengetahuan, pengertian, kepekaan, pemahaman, penikmatan, dan penghargaan terhadap karya sastra tersebut.

\section{Metode}

Model yang digunakan dalam penelitian ini adalah model penelitian dan pengembangan Research and Development ( $\mathrm{R} \& \mathrm{D})$ Borg \& Gall (1983, p.772). Terdapat sepuluh (10) langkah yang diungkapkan Borg \& Gall (1983, p.775) sebagai tahap untuk mengembangkan sebuah produk, yaitu: (1) Research and Information collection, (2) Planning, (3) Develop Preliminary form on product, (4) Preliminary field testing, (5) Main product revision, (6) Main field testing, (7) Operational product revision, (8) Operational field testing, (9) Final product revision, dan (10) Dissemination and implementation. Berdasarkan skema penelitian dan pengembangan Borg \& Gall yang berlangsung dalam 10 langkah, dalam penelitian ini diringkas menjadi 3 langkah, yaitu (1) studi pendahuluan, (2) proses pengembangan, dan (3) uji coba dan finalisasi.

Prosedur pengembangan produk/perangkat pembelajaran dalam penelitian ini melalui empat tahap, yaitu: (a) produk konseptual, (b) produk teoritik, (c) produk hipotetik, dan (d) produk final. Desain uji coba yang dilakukan terdiri atas (a) uji coba lapangan awal (terbatas), (b) uji coba lapangan (luas), dan uji lapangan operasional. Pelaksanaan uji lapangan operasional dilaksanakan di SD Negeri 3 Pancor dan SD Negeri 3 Selong. Dipilihnya dua sekolah ini menjadi tempat uji lapangan operasional karena kedua sekolah ini menjadi pilot project Kurikulum 2013 di Kecamatan Selong, Lombok Timur. Subjek penelitian ini siswa kelas V SD Negeri 3 Pancor dan SD Negeri 3 Selong berjumlah 102 orang siswa.

Teknik pengumpulan data terdiri atas (1) wawancara, (2) angket, (3) observasi, dan (4) tes hasil belajar. Instrumen pengumpulan data berupa (1) lembar wawancara, (2) lembar angket, (3) lembar observasi, dan (4) soal tes. Teknik analisis data sesuai dengan jenis data yang didapatkan. Data kualitatif dianalisis menggunakan teknik interactive analysis. Data kuantitatif dianalisis menggunakan Paired Sample $t$ Test, dan Independent Sample $t$ Test dengan terlebihdahulu melakukan uji prasyarat berupa uji normalitas dan homogenitas.

\section{Hasil dan Pembahasan}

Uji lapangan operasional dilakukan di dua sekolah, yaitu SD Negeri 3 Pancor dan SD Negeri 3 Selong, melibatkan 2 kelas pada ma- 
Jurnal Prima Edukasia, 4 (2), Juli 2016 - 180

Nurul Mu'minin MZ, Suhardi

sing-masing sekolah. Alasan peneliti memilih sekolah tersebut karena merupakan pilot project Kurikulum 2013 di wilayah kecamatan Selong, Lombok Timur dan masih melaksanakan pembelajaran menggunakan Kurikulum 2013 hingga saat ini. Pada uji lapangan operasional di SD Negeri 3 Pancor kelas VA ditentukan oleh peneliti sebagai kelas eksperimen dan kelas VB sebagai kelas kontrol. Begitu pula di SD Negeri 3 Selong kelas VA dipilih sebagai kelas eksperimen dan kelas VB sebagai kelas kontrol. Tidak terdapat alasan khusus terhadap penentuan kelas eksperimen dan kontrol, dikarenakan kelas-kelas yang dipilih menjadi tempat uji lapangan operasional telah memiliki kesamaan dalam hal karakteristik dan sumberdaya siswanya.

Uji lapangan operasional bertujuan untuk menguji efektivitas produk hasil pengembangan. Data yang didapatkan pada uji lapangan operasional meliputi data hasil pelaksanaan pembelajaran yang dilakukan oleh guru dan siswa berupa tes hasil belajar dan hasil observasi pelaksanaan pembelajaran untuk mengukur keterlaksanaan RPP berdasarkan proses pembelajaran yang dilaksanakan. Dalam proses menilai pelaksanaan pembelajaran peneliti melibatkan 2 orang teman sejawat yang bertindak sebagai observer di masing-masing kelas eksperimen pada setiap sekolah.

Uji operasional dilaksanakan selama 5 hari mulai 7-11 April 2015. Selama lima hari guru melakukan proses pembelajaran selama 8 jam dengan menggunakan perangkat pembelajaran hasil pengembangan produk. Observer juga tetap memantau keterlaksanaan proses pembelajaran dan memberikan penilaian dengan cara men-checklish lembar observasi yang telah dibagikan.

Sebelum dilakukan proses pembelajaran peneliti pada hari pertama memberikan pretest untuk mengetahui tingkat pemahaman awal siswa. Hasil pretest dapat dideskripsikan bahwa di SD Negeri 3 Pancor terdapat 6 orang siswa kelas eksperimen yang nilainya melebihi KKM $(65,0)$, sementara 18 siswa lainnya mendapat nilain dibawah KKM dengan jumlah total 24 siswa kelas eksperimen. Nilai tertinggi adalah 78,1 dan nilai terendah adalah 43,7 . Sedangkan di SD Negeri 3 Selong terdapat 8 orang siswa kelas eksperimen yang nilainya melebihi KKM dan 18 orang siswa yang mendapatkan nilai dibawah KKM dengan jumlah total 26 siswa kelas eksperimen. Nilai tertinggi adalah 78,1 dan terendah 40,6 .

Setelah dilakukan proses pembelajaran selama 5 hari dan observasi yang juga dilakukan dengan jumlah hari yang sama didapatkan hasil observasi yang sangat baik. Guru dan siswa telah dapat melaksanakan seluruh kegiatan pembelajaran dengan baik. Pada akhir kegiatan pembelajaran peneliti memberikan posttest untuk mengetahui efektivitas penggunaan produk dalam proses pembelajaran. Berdasarkan hasil pretest dan posttest peneliti kemudian melakukan analisis statistik. Peneliti melakukan uji prasyarat berupa uji normalitas dan homogenitas, selanjutnya menggunakan analisis Paired Sample t Test dan Independent Sample t Test.

Uji Normalitas dan Homogenitas

Uji normalitas dan homogenitas dilakukan terhadap skor pretest dan posttest seluruh subjek uji dengan cara menggabungkan hasil pretest dan posttest seluruh siswa yang berjumlah 102 orang. Out put uji normalitas dan uji homogenitas menggunakan SPSS 16.0 terlihat sebagai berikut:

Tabel 1. Uji Normalitas Pretest

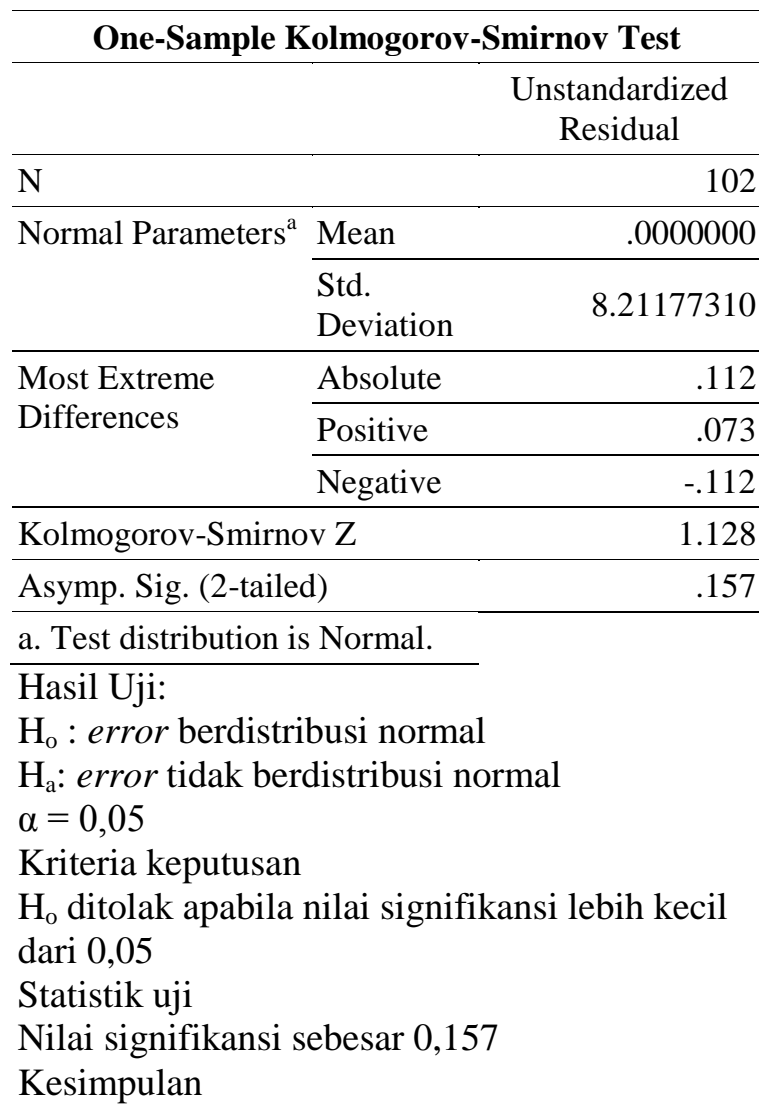


Pada tabel out put One-Sample Kolmogorov-Smirnov Test terlihat bahwa nilai signifikansi lebih besar dari 0,05 untuk Pretest, dinyatakan $\mathrm{H}_{0}$ diterima sehingga dapat disimpulkan error berdistribusi normal. Selanjutnya dilakukan uji homogenitas untuk mengetahui apakah varians populasi identik ataukah tidak dengan hipotesis sebagai berikut:

Tabel 2. Uji Homogenitas Pretest

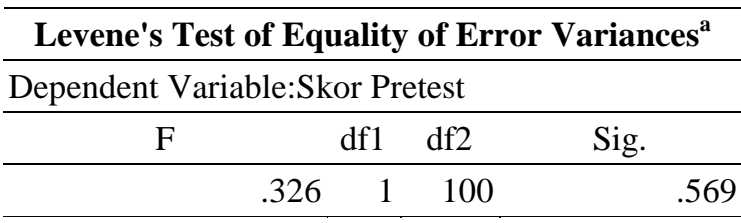

Tests the null hypothesis that the error variance of the dependent variable is equal across groups.

a. Design: Intercept + Keterangan

Ho: Variance populasi nilai tes prestasi belajar dilihat dari pretest antara responden kelas kontrol dan kelas eksperimen adalah sama

Ha: Variance populasi nilai tes prestasi belajar dilihat dari pretest antara responden kelas kontrol dan kelas eksperimen adalah berbeda

Jika Probabilitas $>0,05$, maka H0 tidak dapat ditolak jadi variance sama

Jika Probabilitas $\leq$ 0,05, maka H0 ditolak jadi variance berbeda

\section{Hasil Uji}

Hasil uji levene test menunjukkan nilai $\mathrm{F}$ test sebesar 0,326 dan tidak signifikan pada $0,05(\mathrm{p}=0,569$ atau $\mathrm{p}>0,05)$ yang berarti kita tidak dapat menolak hipotesis nol yang menyatakan variance sama (homogen).

Tabel 3. Uji Normalitas Posttest

\begin{tabular}{llr}
\hline \multicolumn{3}{c}{ One-Sample Kolmogorov-Smirnov Test } \\
\hline & \multicolumn{2}{c}{$\begin{array}{c}\text { Unstandardized } \\
\text { Residual }\end{array}$} \\
\hline $\mathrm{N}$ & \multicolumn{1}{c}{ Mean } & 102 \\
\cline { 2 - 3 } $\begin{array}{l}\text { Normal } \\
\text { Parameters }\end{array}$ & Std. & .0000000 \\
\hline Most Extreme & Deviation & 9.51588219 \\
\cline { 2 - 3 } Differences & Pbsolute & .098 \\
\cline { 2 - 3 } & Positive & .098 \\
\hline Kolmogorov-Smirnov Z & -.063 \\
\hline Asymp. Sig. (2-tailed) & .990 \\
\hline a. Test distribution is Normal.
\end{tabular}

Hasil Uji:

$\mathrm{H}_{\mathrm{o}}$ : error berdistribusi normal

$\mathrm{H}_{\mathrm{a}}$ : error tidak berdistribusi normal

$\alpha=0,05$

Kriteria keputusan

$\mathrm{H}_{\mathrm{o}}$ ditolak apabila nilai signifikansi lebih kecil dari 0,05

Statistik uji

Nilai signifikansi sebesar 0,281

Kesimpulan

Berdasarkan tabel, nilai signifikansi lebih besar dari 0,05 untuk Posttest $\mathrm{H}_{0}$ diterima sehingga dapat disimpulkan error berdistribusi normal.

Uji homogenitas dilakukan untuk mengetahui apakah varians populasi identik ataukah tidak dengan hipotesis sebagai berikut:

Tabel 4. Uji Homogenitas Posttest

\section{Levene's Test of Equality of Error Variances ${ }^{a}$}

Dependent Variable:Skor Postest Kelas Kontrol dan Eksperimen

\begin{tabular}{ccccc}
\hline F & df1 & & df2 & Sig. \\
\hline 1.271 & & 1 & 100 & .262 \\
\hline
\end{tabular}

Tests the null hypothesis that the error variance of the dependent variable is equal across groups.

a. Design: Intercept + Kont_Eks

H0: Variance populasi nilai tes prestasi belajar dilihat dari posttest antara responden kelas kontrol dan kelas eksperimen adalah sama

HA: Variance populasi nilai tes prestasi belajar dilihat dari posttest antara responden kelas kontrol dan kelas eksperimen adalah berbeda

Jika Probabilitas $>0,05$, maka H0 tidak dapat ditolak jadi variance sama

Jika Probabilitas $\leq$ 0,05, maka H0 ditolak jadi variance berbeda

\section{Hasil Uji}

Hasil uji levene test menunjukkan bahwa nilai $F$ test sebesar 1,271 dan tidak signifikan pada $0,05(p=0,262$ atau $p>0,05)$ yang berarti kita kita menerima hipotesis nol yang menyatakan variance sama (homogen).

Paired Sample t Test (Uji Beda t Tes dengan sampel berhubungan)

Paired Sample $t$ Test dilakukan dengan cara menghitung uji beda pretest dan posttest kelas kontrol dan kelas eksperimen. Peneliti menggabungkan subjek kelas eksperimen yang berjumlah 50 orang siswa pada dua sekolah dan 
Jurnal Prima Edukasia, 4 (2), Juli 2016 - 182

Nurul Mu'minin MZ, Suhardi

subjek keas kontrol yang berjumlah 52 orang siswa.

Tabel 5. Uji Beda Pretest dan Posttest Kelas Eksperimen

\begin{tabular}{|c|c|c|c|c|c|}
\hline \multicolumn{6}{|c|}{ Paired Samples Statistics } \\
\hline & & Mean & $\mathrm{N}$ & $\begin{array}{c}\text { Std. } \\
\text { Deviation }\end{array}$ & $\begin{array}{c}\text { Std. } \\
\text { Error } \\
\text { Mean }\end{array}$ \\
\hline \multirow[t]{2}{*}{ Pair 1} & $\begin{array}{l}\text { Pretest Kelas } \\
\text { Eksperimen }\end{array}$ & 60.5540 & 50 & 7.85998 & 1.11157 \\
\hline & $\begin{array}{l}\text { Posttestkelas } \\
\text { Ekasperimen }\end{array}$ & 78.5940 & 50 & 9.54199 & 1.34944 \\
\hline
\end{tabular}

Tabel 6. Uji Signifikansi Hasil Pretest

\begin{tabular}{|c|c|c|c|}
\hline \multicolumn{4}{|c|}{ Paired Samples Test } \\
\hline & & $\mathrm{t} \quad \mathrm{df}$ & $\begin{array}{l}\text { Sig. (2- } \\
\text { tailed) }\end{array}$ \\
\hline $\begin{array}{l}\text { Pair } \\
1\end{array}$ & $\begin{array}{l}\text { Pretest Kelas Eksperimen } \\
\text { - Posttestkelas } \\
\text { Ekasperimen }\end{array}$ & $10.930^{-} 49$ & .000 \\
\hline
\end{tabular}

Pada output bagian pertama yaitu paired sample statistics terlihat bahwa rata-rata pretest kelompok responden kelas Eksperimen adalah 60,55 sedangkan untuk rata-rata posttest kelas eksperimen adalah 78,59. Secara absolut jelas bahwa rata-rata kelas eksperimen berbeda antara pretest dan posttest, untuk melihat apakah perbedaan itu signifikan (nyata secara statistik) maka kita harus melihat output bagian kedua (independent sample t-test).

Pada output bagian kedua dari output SPSS terlihat bahwa nilai $\mathrm{t}$ adalah $-10,930$ dengan probabilitas 0,000 (two tail) kurang dari 0,05. Jadi dapat disimpulkan bahwa Ho ditolak dan Ha diterima atau hasil posttest pada kelas eksperimen lebih baik dibandingkan hasil pretest kelas eksperimen pada taraf signifikansi 0,05 .
Tabel 7. Uji Beda untuk pretest dan posttest kelas kontrol

\begin{tabular}{lllll}
\hline \multicolumn{4}{c}{ Paired Samples Statistics } \\
\hline & Mean & N & $\begin{array}{c}\text { Std. } \\
\text { Deviation }\end{array}$ & $\begin{array}{c}\text { Std. Error } \\
\text { Mean }\end{array}$ \\
\hline $\begin{array}{l}\text { Pair } \\
1\end{array}$ & $\begin{array}{l}\text { Pretest } \\
\text { Kelas } \\
\text { Kontrol } \\
\text { Posttest } \\
\text { Kelas } \\
\text { Kontrol }\end{array}$ & 61.869252 & 8.61323 & 1.19444 \\
\hline
\end{tabular}

Tabel 8. Uji Signifikansi Hasil Posttest

\begin{tabular}{|c|c|c|c|}
\hline \multicolumn{4}{|c|}{ Paired Samples Test } \\
\hline & & $\mathrm{t} \quad \mathrm{df}$ & $\begin{array}{l}\text { Sig. (2- } \\
\text { tailed) }\end{array}$ \\
\hline $\begin{array}{c}\text { Pair } \\
1\end{array}$ & $\begin{array}{l}\text { Pretest Kelas Kontrol - } \\
\text { Posttest Kelas Kontrol }\end{array}$ & ${ }_{8.763}^{-} 51$ & .000 \\
\hline
\end{tabular}

Pada output bagian pertama yaitu paired sample statistics terlihat bahwa rata-rata pretest kelompok responden kelas kontrol adalah 61,87 sedangkan untuk rata-rata posttest kelas kontrol adalah 72,46 . Secara absolut jelas bahwa ratarata kelas kontrol berbeda antara pretest dan posttest, untuk melihat apakah perbedaan itu signifikan (nyata secara statistik) maka kita harus melihat output bagian kedua (independent sample $t$-test).

Pada output bagian kedua dari output SPSS terlihat bahwa nilai $\mathrm{t}$ adalah $-8,763$ dengan probabilitas 0,000 (two tail) kurang dari 0,05 . Jadi dapat disimpulkan bahwa Ho ditolak dan Ha diterima atau hasil posttest kelas kelas kontrol lebih baik dibandingkan hasil pretest kelas kontrol pada taraf signifikansi 0,05.

\section{Independent Sample t Test}

Independent Sample $t$ Test dilakukan dengan cara menghitung uji t pretest kelas kontrol dan kelas eksperimen, dilanjutkan dengan menghitung uji $\mathrm{t}$ posttest kelas kontrol dan kelas eksperimen. Peneliti menggabungkan subjek uji pada kelas kontrol yang berjumlah 52 orang siswa dan kelas eksperimen yang berjumlah 50 orang siswa dari 2 sekolah. 
Jurnal Prima Edukasia, 4 (2), Juli 2016 - 183

Nurul Mu'minin MZ, Suhardi

Tabel 9. Uji t Pretest

\begin{tabular}{cccccc}
\hline \multicolumn{6}{c}{ Group Statistics } \\
\hline Kelas Kontrol dan Eksperimen & $\mathrm{N}$ & Mean & Std. Deviation & Std. Error Mean \\
\hline \multirow{2}{*}{ Skor Pretest } & Kelas Kontrol & 52 & 61.8692 & 8.61323 & 1.19444 \\
\cline { 2 - 6 } & Kelas Eksperimen & 50 & 60.5540 & 7.85998 & 1.11157 \\
\hline
\end{tabular}

Tabel 10. Uji Signifikansi Pretest

\begin{tabular}{|c|c|c|c|c|c|c|c|}
\hline \multicolumn{8}{|c|}{ Independent Samples Test } \\
\hline & \multicolumn{7}{|c|}{ t-test for Equality of Means } \\
\hline & \multirow[t]{2}{*}{$\mathrm{T}$} & \multirow[t]{2}{*}{ Df } & \multirow{2}{*}{$\begin{array}{c}\text { Sig. } \\
\text { (2-tailed) }\end{array}$} & \multirow{2}{*}{$\begin{array}{c}\text { Mean } \\
\text { Difference }\end{array}$} & \multirow{2}{*}{$\begin{array}{l}\text { Std. Error } \\
\text { Difference }\end{array}$} & \multicolumn{2}{|c|}{$\begin{array}{l}\text { 95\% Confidence Interval } \\
\text { of the Difference }\end{array}$} \\
\hline & & & & & & Lower & Upper \\
\hline Equal variances assumed & .805 & 100 & .423 & 1.31523 & 1.63460 & -1.92777 & 4.55823 \\
\hline Equal variances not assumed & .806 & 99.732 & .422 & 1.31523 & 1.63165 & -1.92202 & 4.55248 \\
\hline
\end{tabular}

Tabel 11. Uji t Posttest

\begin{tabular}{|c|c|c|c|c|c|}
\hline \multicolumn{6}{|c|}{ Group Statistics } \\
\hline & Keterangan & $\mathrm{N}$ & Mean & Std. Deviation & Std. Error Mean \\
\hline \multirow[t]{2}{*}{ Skor Postest Kelas Kontrol dan Eksperimen } & Kelas Kontrol & 52 & 72.4596 & 9.58382 & 1.32904 \\
\hline & Kelas Eksperimen & 50 & 78.5940 & 9.54199 & 1.34944 \\
\hline
\end{tabular}

Tabel 12. Uji Signifikansi Posttest

\begin{tabular}{|c|c|c|c|c|c|c|c|}
\hline \multicolumn{8}{|c|}{ Independent Samples Test } \\
\hline & \multicolumn{7}{|c|}{ t-test for Equality of Means } \\
\hline & \multirow[t]{2}{*}{$\mathrm{t}$} & \multirow[t]{2}{*}{ df } & \multirow{2}{*}{$\begin{array}{c}\text { Sig. } \\
\text { (2-tailed) }\end{array}$} & \multirow{2}{*}{$\begin{array}{c}\text { Mean } \\
\text { Difference }\end{array}$} & \multirow{2}{*}{$\begin{array}{l}\text { Std. Error } \\
\text { Difference }\end{array}$} & \multicolumn{2}{|c|}{$\begin{array}{c}95 \% \text { Confidence Interval } \\
\text { of the Difference }\end{array}$} \\
\hline & & & & & & Lower & Upper \\
\hline Equal variances assumed & -3.239 & 100 & .002 & -6.13438 & 1.89419 & -9.89240 & -2.37637 \\
\hline Equal variances not assumed & -3.239 & 99.876 & .002 & -6.13438 & 1.89402 & -9.89213 & -2.37664 \\
\hline
\end{tabular}

Berdasarkan output bagian pertama groups statistics terlihat bahwa rata-rata pretest kelompok responden kelas kontrol adalah 61,87 sedangkan untuk kelompok responden kelas eksperimen adalah 60,55. Secara absolut jelas bahwa rata-rata pretest berbeda antara kelas kontrol dan kelas eksperimen walaupun selisihnya tidak lebih dari dua, untuk melihat apakah perbedaan itu signifikan (nyata secara statistik) maka kita harus melihat output bagian kedua (independent sample t-test).

Sedangkan pada output bagian kedua dapat disimpulkan berdasarkan uji sebelumnya pada uji homogenitas disimpulkan variance sama atau homogen, dengan demikian analisis uji beda t-Test harus menggunakan asumsi equal variance assumed. Dari output SPSS terlihat bahwa nilai t pada equal variance assumed adalah 0,805 dengan probabilitas 0,423 (two tail). Jadi dapat disimpulkan bahwa tidak terdapat perbedaan secara signifikan antara rata-rata skor pretest kelas kontrol dan rata-rata skor pretest kelas eksperimen.

Berdasarkan output bagian pertama groups statistics terlihat bahwa rata-rata posttest kelompok responden kelas kontrol adalah 72,46 sedangkan untuk kelompok responden kelas eksperimen adalah 78,59. secara absolut jelas bahwa rata-rata posttest berbeda antara kelas kontrol dan kelas eksperimen, untuk melihat apakah perbedaan itu signifikan (nyata secara statistik) maka kita harus melihat output bagian kedua (independent sample t-test).

Output bagian kedua sesuai dengan uji sebelumnya yaitu uji homogenitas disimpulkan variance sama atau homogen, dengan demikian analisis uji beda t-test harus menggunakan asumsi equal variance assumed. Dari output 
Jurnal Prima Edukasia, 4 (2), Juli 2016 - 184

Nurul Mu'minin MZ, Suhardi

SPSS terlihat bahwa nilai t pada equal variance assumed adalah -3,239 dengan probabilitas 0,002 (two tail). Jadi dapat disimpulkan bahwa terdapat perbedaan secara signifikan antara rata-rata hasil posttest kelas kontrol dan ratarata skor pretest kelas eksperimen. Jadi dapat disimpulkan bahwa Ho ditolak dan Ha diterima atau hasil posttest kelas eksperimen lebih baik dibandingkan hasil posttest kelas kontrol pada taraf signifikansi 0,05 .

\section{Simpulan dan Saran}

\section{Simpulan tentang Produk}

Produk hasil pengembangan perangkat pembelajaran tematik integratif berbasis sastra telah dinyatakan layak untuk digunakan oleh ahli materi dan ahli pembelajaran dengan memberikan kriteria skor "baik".

Berdasarkan rata-rata post tes kelas kelas kontrol 72,46 dan posttest kelas eksperimen 78,59 secara absolut jelas terdapat perberdaan. Uji t terhadap nilai hasil belajar siswa kelas kontrol dan kelas eksperimen didapatkan nilai $t$ $-3,239$ dengan probabilitas 0,002 (two tail). Jadi dapat disimpulkan terdapat perbedaan yang signifikan hasil posttest kelas eksperimen dan posttest kelas kontrol.

Saran Pemanfaatan Produk

\section{Bagi Sekolah}

Produk hasil pengembangan dapat dijadikan contoh bagi sekolah untuk menyusun perangkat pembelajaran yang serupa atau identik dengan ciri khas yang lainnya. Produk hasil pengembangan dapat menjadi acuan pelaksanaan pembelajaran tematik integratif sesuai Kurikulum 2013 khususnya di kelas V.

\section{Bagi Guru}

Produk hasil pengembangan perangkat pembelajaran tematik integratif berbasis sastra diharapkan dapat digunakan oleh guru dengan tujuan untuk dapat menciptakan suasana pembelajaran yang menyenangkan dan menarik minat siswa dalam proses pembelajaran. Produk hasil pengembangan dapat dijadikan acuan (contoh) dalam membuat perangkat pembelajaran serupa dengan subtema atau tema yang berbeda.

\section{Bagi Siswa}

Produk hasil pengembangan perangkat pembelajaran tematik integratif berbasis sastra diharapkan dapat digunakan oleh siswa sebagai bahan ajar untuk lebih menguasai materi tema Organ Tubuh Manusia dan Hewa, subtema Cara Hidup Manusia, Hewan, dan Tumbuhan. Produk hasil pengembangan diharapkan dapat menjadikan pembelajaran menjadi bermakna dan meningkatkan hasil belajar siswa.

\section{Bagi Peneliti}

Produk hasil pengembangan perangkat pembelajaran tematik integratif berbasis sastra diharapkan dapat dijadikan masukan untuk mengasilkan karya ilmiah lainnya.

Diseminasi dan Pengembangan Produk Lebih Lanjut

Produk hasil pengembangan perangkat pembelajaran tematik integratif berbasis sastra dapat diadopsi oleh sekolah-sekolah yang melaksanakan pembelajaran menggunakan Kurikulum 2013, atau oleh sekolah-sekolah pilot projet Kurikulum 2013 di daerah lain secara menyeluruh atau dengan melakukan perubahan untuk menyesuaikan kondisi di wilayah tersebut.

Produk hasil pengembangan perangkat pembelajaran tematik integratif berbasis sastra diharapkan dapat didesiminasikan pada sekolah-sekolah pelaksana Kurikulum 2013 baik SD maupun MI.

Produk hasil pengembangan perangkat pembelajaran tematik integratif berbasis sastra dapat dikembangkan lebih lanjut pada materi yang berbeda.

\section{Daftar Pustaka}

Borg, W. R. \& Gall, M. D. (1983). Educational research. New York \& London: Longman.

Ismawati, E. (2013). Pengajaran sastra. Yogyakarta: Ombak.

Fogarty, R. (1991). How to integrate the curricula. Palatine: Skylight Publising Inc.

Haryadi. (2011). Peran sastra dalam pembentukan karakter bangsa. Yogyakarta: Universitas Negeri Yogyakarta. 
Jurnal Prima Edukasia, 4 (2), Juli 2016 - 185

Nurul Mu'minin MZ, Suhardi

Jakman, H. L. (2012). Early educational curriculum: a child's conection to the world $5^{\text {th }} e d$. Boston: Wadsworth, Cengange Learning.

Madjid, A. (2009). Perencanaan pembelajaran mengembangkan standar kompetensi guru. Bandung: Remaja Rosdakarya.

Moore, K. D. (2012). Effective instructional strategies, from theory to practice. Thousand Oaks, California: SAGE.

O’Brien, J. G., Millis, B. J., Cohen, M. W. (2007). The course syllabus: a learning centered approach $2^{\text {nd }}$ ed. Boston: Jossey-Bass.

O’Brien, J. G., Millis, B. J., Cohen, M. W. (2010). Undang-undang RI Nomor 20
Tahun 2003 tentang SISDIKNAS \& Peraturan Pemerintah RI Tahun 2010 tentang Penyelenggaraan Pendidikan serta Wajib Belajar. Bandung: Citra Umbara

Suhadi. (2007). Penyusunan perangkat pembelajaran dalam kegiatan lesson study. Diambil pada tanggal 30 Januari 2015, dari https://suhadinet.wordpress.com/2008/0 5/28/penyusunan-perangkatpembelajaran-dalam-kegiatan-lessonstudy/

Sukardi. (2009). Metodologi penelitian pendidikan. kompetensi dan praktiknya. Jakarta: Bumi Aksara. 